\title{
Teaching NeuroImages: Enlarged parietal foramina inadvertently labeled as burr holes
}

Juan Fernandez, MD, Sarah Woodson, MD, and Kevin Cannard, MD

Neurology ${ }^{\circledR}$ 2019;93:e827-e828. doi:10.1212/WNL.0000000000007978
Correspondence

Dr. Fernandez

jdfs1989@gmail.com

Figure CT scan of the head and anteroposterior (AP) skull X-ray show enlarged parietal foramina (EPF)

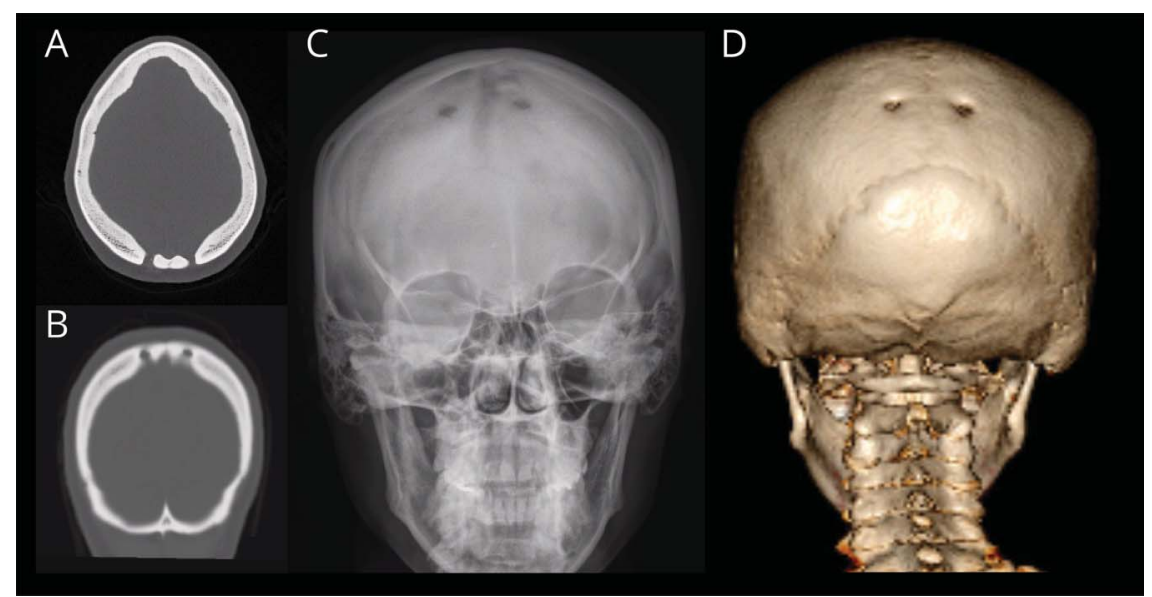

Axial (A) and coronal (B) CT bone window images, AP skull $X$-ray $(C)$, and a $3 D$ rendering of the $C T$ scan of the head (D) show symmetric oval foramina roughly $50 \times 50 \mathrm{~mm}$ in diameter encompassing the entire depth of the parietal bones consistent with EPF.
A 49-year-old woman presented with status migrainosus. A CT head revealed only bilateral symmetric burr holes in the posterior paramedian calvarium despite no prior cranial surgery (figure). These holes ultimately represented enlarged parietal foramina (EPF) unrelated to her presentation. EPF are rare developmental defects of the parietal bones (prevalence of 1 : $15,000-50,000)$ commonly due to an abnormal ossification pattern associated with heterogeneous homeobox gene mutations. Though rarely associated with craniofacial and vascular malformations, headaches, and epilepsy, EPF are usually benign, incidental findings, ranging from few millimeters to several centimeters in diameter, and frequently located in the upper, posterior parietal bones. ${ }^{1,2}$

\section{Study funding}

No targeted funding reported.

\section{Disclosure}

The authors report no disclosures relevant to the manuscript. The views expressed in this article are those of the authors and do not reflect the official policy of the Department of Army, Navy, Air Force, Department of Defense, or US Government. Go to Neurology.org/N for full disclosures.

\section{References}

1. Durão C, Carpinteiro D, Pedrosa F, Machado MP, Cunha E. Enlarged parietal foramina: a rare forensic autopsy finding. Int J Leg Med 2016;130:855-857.

2. Griessenauer CJ, Veith P, Mortazavi MM, et al. Enlarged parietal foramina: a review of genetics, prognosis, radiology, and treatment. Childs Nerv Syst 2013;29:543-547.

\section{MORE ONLINE}

\section{$\rightarrow$ Teaching slides}

links.lww.com/WNL/

A943. 
Appendix Authors

\begin{tabular}{lll}
\hline Name & Location & Role contribution \\
\hline $\begin{array}{l}\text { Juan } \\
\text { Fernandez, } \\
\text { MD }\end{array}$ & $\begin{array}{l}\text { WRNMMC, } \\
\text { Bethesda, MD }\end{array}$ & $\begin{array}{l}\text { Case report concept, design and critical } \\
\text { revision of content, takes responsibility } \\
\text { for the data, the analyses and } \\
\text { interpretation, and the conduct of the } \\
\text { case report }\end{array}$ \\
$\begin{array}{l}\text { Sarah } \\
\text { Woodson, } \\
\text { MD }\end{array}$ & $\begin{array}{l}\text { WRNMMC, } \\
\text { Bethesda, MD }\end{array}$ & $\begin{array}{l}\text { Critical revision of the manuscript } \\
\text { content and figure design }\end{array}$ \\
$\begin{array}{l}\text { Kevin } \\
\text { Cannard, } \\
\text { MD }\end{array}$ & $\begin{array}{l}\text { WRNMMC, } \\
\text { Bethesda, MD }\end{array}$ & $\begin{array}{l}\text { Critical revision of the manuscript } \\
\text { content and figure design }\end{array}$ \\
\hline
\end{tabular}




\section{Neurology}

\section{Teaching NeuroImages: Enlarged parietal foramina inadvertently labeled as burr holes}

Juan Fernandez, Sarah Woodson and Kevin Cannard

Neurology 2019;93;e827-e828

DOI 10.1212/WNL.0000000000007978

This information is current as of August 19, 2019

\section{Updated Information \& Services}

References

Subspecialty Collections

Permissions \& Licensing

\section{Reprints}

including high resolution figures, can be found at: http://n.neurology.org/content/93/8/e827.full

This article cites 2 articles, 0 of which you can access for free at: http://n.neurology.org/content/93/8/e827.full\#ref-list-1

This article, along with others on similar topics, appears in the following collection(s):

All Genetics

http://n.neurology.org/cgi/collection/all_genetics All Headache

http://n.neurology.org/cgi/collection/all_headache CT

http://n.neurology.org/cgi/collection/ct

Information about reproducing this article in parts (figures,tables) or in its entirety can be found online at:

http://www.neurology.org/about/about_the_journal\#permissions

Information about ordering reprints can be found online:

http://n.neurology.org/subscribers/advertise

Neurology ${ }^{\circledR}$ is the official journal of the American Academy of Neurology. Published continuously since 1951, it is now a weekly with 48 issues per year. Copyright () 2019 American Academy of Neurology. All rights reserved. Print ISSN: 0028-3878. Online ISSN: 1526-632X.

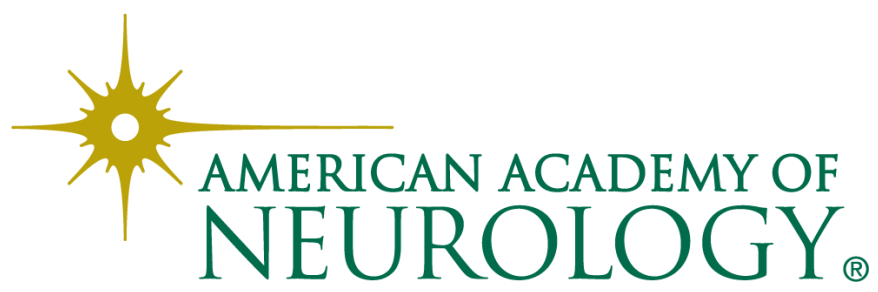

